\title{
MECHANICAL LOAD CAUSED BY PHYSICAL ACTIVITY BY WEARING MILITARY EQUIPMENT
}

\author{
Tomislav Babić
}

Student, Polytechnic of Rijeka, Vukovarska 58, 51000 Rijeka, Croatia; e-mail: tomislavbabic94@gmail.com.

\section{Marko Kršulja}

PhD, Assistant professor, University of Pula, Zagrebačka 30, 52100 Pula, Croatia; e-mail:mkrsulja@unipu.hr

\section{Maja Šupuković}

Assistant, Polytechnic of Rijeka, Vukovarska 58, 51000 Rijeka, Croatia; e-mail: msupukov@veleri.hr

\begin{abstract}
In this paper fatigue for professional soldier caused by active physical activity and endurance limits is investigated. The resulting workload is one of indicators of how training, preparedness and other acquired work skills can contribute to the human body being a large working "machine". Ergometry test was conducted and field test for soldier fitness condition and energy expenditure was measured regarding the level of body's metabolism. Field test consisted of three runs on a polygon of $10 \mathrm{~km}$ and different workloads, the energy consumption was monitored. Work load was compared with Occupational Safety and Health law acts. The results showed difference in workload conditions and hart rate which allowed to determine rest spots and safety in training conditions.
\end{abstract}

Key words: fatigue, metabolism, energy expenditure, occupational safety, soldier

\section{INTRODUCTION}

Fitness for duty is something that is important in occupational safety, as it influences alertness that individuals need while preforming safety sensitive work. Alertness is influenced by what one does as current operation, by sleep quality, by management of fatigue, by medical issues from work related sources or by personal health issues. Potential consequences of low alertness are injuries at work therefore safety risk must be managed, between 1996 and 2016, 434121 occupational injuries were reported in the Republic of Croatia (Pupovac et al., 2018). For professional soldiers one of issues to consider are work shifts that can be fulltime on evening, night, or rotating shifts, or other employer-arranged irregular schedules. If it relates to performing an action on a training ground or during other military exercises, then these are jobs with special working conditions from the Ordinance (Official Gazette 5/84). According to the Occupational Safety and Health Act (Official Gazette $71 / 14,118 / 14$ and 154/14), which means safety, access to safety and wearing protective 
clothing and footwear. Also, from the Ordinance on Occupational Safety at Manual Handling of Loads (OG No. 42/05) restrictions on the workload of workers. And from the Law on Service in the Armed Forces of the Republic of Croatia (Official Gazette 73/15, 75/15, 50/16 and 30/18), which must be fulfilled in order to become an active military person. And it depends on the specialization that the tests must pass in order to be able to perform a military job and advance in a military career. Dangers like bad lighting, sound, vibration or extreme temperature changes are present in the field of work of soldiers and can influence overall fitness status. However physical dangers are more often categorized as work diseases that affect hands, hearing problems, cardiovascular problems, eyes problems, skin problems, (Regent, 2015). Repetitive high load work can be subjected to cause heat stress if working conditions aren't meet according legal recommendations (Bognolo et al., 2015).

The hypothesis is that a professional soldier can withstand proper exercise and preparation to withstand the stress of the body, that is, to achieve maximum load under difficult conditions on the training ground, which he would not be able to do without preparation.

The subject of the final work is based on the fact that hard work and easier work with different combat equipment was performed, when collecting data in the field. The requirement is that a professional soldier, in addition to his job, must satisfy the criteria of psycho-physical education, in addition to his military duty. Measurements were made visually and using devices for analyzing the fitness of soldiers.

Physical exercise induces adaptations in metabolism that improve overall cardiac metabolism and capacity of people to perform more demanding tasks. However, in order to achieve significant therapeutic relevance that boosts energetic aspect of a person it is required to maintain proper training, and correct nutrition in individuals. There is a risk when modulating cardiac metabolism in heart failure. In this paper such investigation is conducted for workload of soldiers that are subjected with intense workload and continuous exercise, training, and competitions. It is necessary to monitor type of work being done and in what conditions such work is performed in order to secure occupational safety.

Aim of this paper is to investigate loading dose of physical activities of professional soldier, with correlation to endurance limits. There is a need to find relation between load and metabolism on practical example and to offer recommendation for purposes of increasing knowledge for this type of work. It is important to explain what metabolism is. Point out the dangers of mechanical loading. Explain legislation for special work conditions. Demonstrate required energy intake. Demonstrate work skills on a training ground. Suggest safeguards if dangerous situations occur.

\section{POWER CONSUMPTION AT WORK}

All activity that is performed at work uses energy, this energy can be used to compare different physical stresses, but it cannot be used for measuring mental activity and skill level. Attitudes of the body at work can also have a significant impact on energy consumption. Such as sitting (3-5 $\%)$, sitting $(8-10 \%)$, bending $(50-60 \%)$, kneeling (30 - $40 \%$ ). Total energy consumed in a day is as follows: 1. basal metabolism 2. energy for work 3. energy for other activities. 
For soldiers' active culture of health is a must, therefore supportive work environment must be obtained for managing alertness and one of main things to monitor is metabolism. Metabolism is conversion of chemical energy to body energy by transforming nutrients into warmth, mechanical work, assimilated organic matter (fat reserves) and wasted energy in urine + feces. Therefore, basal metabolism covers basic life functions at rest where average person needs about $70-80 \mathrm{~W}$ of heat ( $1 \mathrm{kcal} / \mathrm{kg} \mathrm{h}=1 \mathrm{BMR}$ ). With this energy a person is enabled to perform work tasks that require different workloads. 1 MET (Metabolic Equivalent of Task) is defined by ANSI / ASHRAE Standard 55 as $58.2 \mathrm{~W} / \mathrm{m}^{2}$, which is the amount of heat a person produces when sitting still. In relation to metabolism we can assume that for light work the metabolic effect is up to $M=2=116 \mathrm{~W} / \mathrm{m}^{2}$; while for medium heavy duty, $M=2.6=150 \mathrm{~W} / \mathrm{m}^{2}$; and for heavy work like soldiers $M=4.7=275$ $\mathrm{W} / \mathrm{m}^{2}$.

Nutrition consists of the necessary intake of food and drink for the functioning of the body and restore spent energy or metabolism. Only a small amount of food is used for the repair of body tissues or stored as fat reserves. It is assumed that average person moderately active needs around 2,000 calories a day for women and 2,500 for men every day to maintain energy and weight. It is related to age, gender and physical activity level, (Bender 2007.). The main nutrients are eaten in large quantities and are protein, carbohydrates, and fat while small dosage nutrients are vitamins, minerals and very important water. The metabolism of these fuels results in the production of carbon dioxide and water. The same energy can be gained by burning in air and fundamental law of chemistry states that if the starting material and end products are the same, the energy yield is the same. Therefore, energy consumption is measured by body heat output with calorie (Cal) signifying required heat to raise temperature of $1 \mathrm{~g}$ of water by $1^{\circ} \mathrm{C}$. For energy purposes conversion of calories and joules is used as $1 \mathrm{kcal}=4.186 \mathrm{~kJ}, 1 \mathrm{~kJ}=0.239 \mathrm{kcal}$. Approximatively for women 2000 calories $=8.372 \mathrm{MJ}$ and 2500 for men $10.465 \mathrm{MJ}$. In table 1 some energy values for food is shown table 1 (Bender, 2007).

Table 1. Energy values of metabolic food conversion

\begin{tabular}{|l|c|c|c|}
\hline & Kcal/g & KJ/g & KJ/g \\
\hline Carbohydrate & 4 & 16744 & 17 \\
\hline Protein & 4 & 16744 & 16 \\
\hline Fat & 9 & 37674 & 37 \\
\hline \multicolumn{2}{|c|}{ Source: Bender (2007) }
\end{tabular}

For example, if a soldier is extra active (exercises \& physical job or $2 x$ training) then he could spend 2.8 MET and if his weight is $70 \mathrm{~kg}$ and body surface of $1.847 \mathrm{~m}^{2}$ then he spends $300.97 \mathrm{~W}$. It can be calculated from knowing that $Q_{\mathrm{baz}} \approx m \cdot q \cdot 24[\mathrm{~kJ} /$ day], where $q=4,19 \mathrm{~kJ} /(\mathrm{kg} \cdot \mathrm{h})$, and basic metabolism $Q_{M 1}=1 \mathrm{MET} \cdot \mathrm{A}=58.2 \cdot 1.847=107.49 \mathrm{~W}$, then the energy expenditure results as $Q_{M}=2.8 \mathrm{MET} \cdot 107.49$ $\mathrm{W}=300.97 \mathrm{~W}=300.97 \mathrm{Js}^{-1}$.

If he works 7.5 hours $1 \mathrm{~h}=3600 \mathrm{~s}$, during work time (7.5 h.3600 s = $27000 \mathrm{~s})$ then spent energy results in $Q=27000 \mathrm{~s} \cdot 300.97 \mathrm{Js}^{-1}=8126190 \mathrm{~J}=8126.19 \mathrm{~kJ}$. 
The soldier needs to recuperate lost energy by eating, the average diet should provide about $55 \%$ of energy from carbohydrates, $30 \%$ from fat, and $15 \%$ from protein, the ratio can be for athletes also $70 \%$ carbohydrates, fat / $12 \%$ fat / $18 \%$ protein or $60 \%$ carbohydrates $/ 2512 \%$ fat $/ 15 \%$ protein, (Manoroe 2009.).

$C_{\text {carbohydrates }}=0,55.8126 .19 \mathrm{~kJ}=4469.40 \mathrm{~kJ}$ that is equivalent to $4469.40 \mathrm{~kJ} /(16744 \mathrm{~kJ} / \mathrm{kg})=266.9 \mathrm{~g}$.

$\mathrm{C}_{\text {protein }}=0,15.8126 .19 \mathrm{~kJ}=1218.92 \mathrm{~kJ}$ that is equivalent to $1218.92 \mathrm{~kJ} /(16744 \mathrm{~kJ} / \mathrm{kg})=72.7 \mathrm{~g} . \mathrm{C}_{\mathrm{fat}}=$ $0,3 \cdot 8126.19 \mathrm{~kJ}=2437.8 \mathrm{~kJ}$ that is equivalent to $2437.8 \mathrm{~kJ} /(37674 \mathrm{~kJ} / \mathrm{kg})=64.7 \mathrm{~g}$.

For maintaining energy used for extra active job he needs to eat 266.9 grams of carbohydrates, 72.7 grams of protein and 64.7 grams of fat.

\section{CONDITIONAL PREPARATION OF SOLDIERS}

The importance and purpose of each soldier's fitness is fitness training and achieving optimal alertness that he can use in real combat action. One of these conditions is health status and another is ergonomics the repeatability and training of interaction with things and procedures.

Health status of soldiers is a basic prerequisite for any type of training and general exercise. Members of the Armed Forces, unlike individual athletes or the sports team, must maintain fitness throughout their military careers. And they do this through the various activities they are assigned to in order to achieve preparedness and manage fatigue related to a selected task. The importance of maintaining optimum health status is largely aided by preventive and rehabilitation fitness programs aimed at reducing the number and severity of injuries. There are different needs in the Air Force, the Army, Navy, Special Forces or Military Police. Soldiers members must show their "excellent form" throughout the year in various tests and that can be done by detecting health risks. Just as their passing on fitness tests should not be questioned, in order to increase the health status of soldiers, anthropometric measurements are performed in the thickness assessment.

Special attention in training should be done to ergonomically interaction when doing physical work with a thing of interest, with proper body motion a certain task can be done with less energy and less fatigue. With repeated actions such as working with certain equipment, using repetitive procedures there comes an adaptation to that work. The degree of strain depends not only on the number of $k$ J consumed, but also on the number of muscles involved in the work, and the magnitude of the static load to which they are exposed. Care should be taken and muscle contractions that provide energy form mechanical work monitored. After contractions, while the muscle is relaxed and rested, energy reserves are restored. Both processes release energy and renewal occur in the muscle while working. If the energy requirement exceeds the possibility of regeneration, the metabolic balance is disturbed, resulting in a loss of muscle capacity.

Ergonomics also take in consideration temperature, humidity and other factors that influence people while doing work. The energy consumed is not sensitive to these factors, but heart rate is, and therefore the Ordinance on Occupational Safety at Work (Official Gazette 29/13), Article 24 sets out the obligations of employers to achieve a microclimate with regard to the severity of work. So, it is designed for work without physical stress of $20-25^{\circ} \mathrm{C}$, for light physical work of $16-22^{\circ} \mathrm{C}$, heavy 
physical work of $10-19{ }^{\circ} \mathrm{C}$. Also, the ideal humidity is from $40 \%$ to $60 \%$ while $50 \%$ would be ideal. Below $40 \%$ dry air and above because of body sweating requires more liquids to be consumed.

Therefore, if we monitor work conditions and use fewer muscles, use more static work and optimal temperature and humidity we can decrease stress and detect safety risks.

\section{METODOLOGY}

In order to determine workload of a soldier during a regular extra active fitness run. Before run a classic an ergonomic test was preformed and after the soldier run a track long around $9.6 \mathrm{~km}$. The run was done three times on separate days without load, with $10 \mathrm{~kg}$ load and with $20 \mathrm{~kg}$ load in backpack. Standard equipment that was not taken in consideration and calculation was around $7.5 \mathrm{~kg}$ from helmet $4 \mathrm{~kg}$, boots $2.5 \mathrm{~kg}$, belt $0.5 \mathrm{~kg}$, military clothes $0.5-1 \mathrm{~kg}$.

The ergonomic load test is continuous and progressive usually it is used for athletes or persons with hart conditions. Test monitors values of blood pressure and pulse, changes in the ECG and subjective problems of the subjects (chest pain, shortness of breath, leg pain, dizziness, etc.) are recorded. It consists of several stages of work loading with duration of 3 minutes or less for a stage. Ergometry can determine maximum heart rate and maximum blood pressure where test can be maximum or submaximal. The maximum load test is one in which the maximum heart rate determined for the age and gender of the subjects is reached. Whereas the submaximal loading test is one in which the submaximal heart rate is reached, which is $85-90 \%$ of the maximum heart rate.

The ergonomic test was done in medical clinic Medico special hospital in the city of Rijeka. The subject was a man 25 years old height $172 \mathrm{~cm}$ and weight $72 \mathrm{~kg}$. During the performance of the ergometric test according to the Bruc Protocol, the following were obtained:

- load 1, 2.4 / 25 MET/ W 97 beats / min, blood pressure 139/62 mm / Hg.

- $\operatorname{load}$ 5, 7.1 / 125 MET/ W 133 beats / min, blood pressure 157/63 mm / Hg.

- load 10, 13.1 / 250 MET/ W 182 beats / min, blood pressure 194/83 mm / Hg.

Total time of test lasted 27.54 minutes, time of workload was 18.36 minutes, time of resting lasted 4.55 minutes and preparation time was 4.23 minutes.

Polygon test was done on path shown in figure 1, specific location consisting of road, forest and gravel road. The run was executed three times, once without load, once with $10 \mathrm{~kg}$ load and once with $20 \mathrm{~kg}$ load. The objective was to measure workload and results were obtained using the Polar digital watch and polar web application. The runs were conducted 3 days in a row from 15 to 18 of November, from $10 \mathrm{am}$ to $12 \mathrm{am}$, temperature was $20^{\circ} \mathrm{C}$ and four soldiers were running together. 
T. Babić, M. Kršulja, M. Šupuković: Mechanical load caused by physical activity by wearing military... Zbornik Veleučilišta u Rijeci, Vol. 9 (2021), No. 1, pp. 387-399

Figure 1. Polygon track of $10 \mathrm{~km}$ where test was conducted

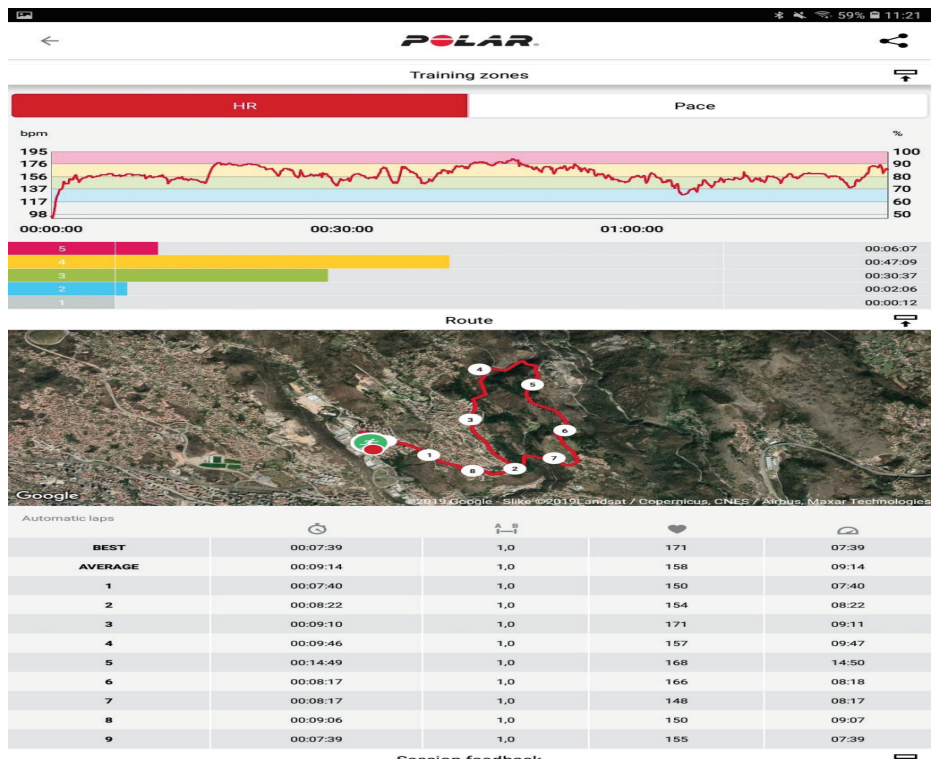

Source: Babić (2020)

\section{RESULTS AND DISCUSSION}

\section{1 Ergometric test}

Results of ergonomic test are shown in table 2, 3 and graph 1.

Table 2. Maximal workload achieved on ergonomic test

\begin{tabular}{|c|c|}
\hline Max. workload & $13.1 / 250(214)$ Met/W $(117,0) \%$ \\
\hline Max. HR & $184(195) / \mathrm{min}(94 \%)$ \\
\hline Max. BP & $194 / 83 \mathrm{mmHg}$ \\
\hline Max. BP x HR & $353 \mathrm{mmHg} / \mathrm{min}$ \\
\hline Min. BP x HR & $150 \mathrm{mmHg} / \mathrm{min}$ \\
\hline DP- factor & 2.4 \\
\hline Body surface & $1.847 \mathrm{~m}$ \\
\hline PWC 150/170 & $159 / 216 \mathrm{~W}$ \\
\hline PWC rel & $2.21 / 3.00 \mathrm{~W} / \mathrm{kg}$ \\
\hline
\end{tabular}


T. Babić, M. Kršulja, M. Šupuković: Mechanical load caused by physical activity by wearing military... Zbornik Veleučilišta u Rijeci, Vol. 9 (2021), No. 1, pp. 387-399

Table 3. Incremental increase of workload results of ergonomic test

\begin{tabular}{|c|c|c|c|c|c|}
\hline \multicolumn{7}{|c|}{ Protocol } & \multicolumn{1}{c|}{ ST@ + 40 ms } \\
\hline & $\begin{array}{c}\text { Time } \\
\text { mm:ss }\end{array}$ & Workload Met/W & HR (/min) & BP (mmHg) & ST V5 (mm) \\
\hline Before & $4: 23$ & $1.2 / 0$ & 106 & $142 / 79$ & 1.3 \\
\hline Load 1 & $2: 08$ & $2.4 / 25$ & 97 & $139 / 62$ & 1.4 \\
\hline Load 2 & $4: 03$ & $3.6 / 50$ & 117 & $138 / 64$ & 1.2 \\
\hline Load 3 & $5: 46$ & $4.8 / 75$ & 112 & $152 / 62$ & 1.1 \\
\hline Load 4 & $7: 46$ & $6.0 / 100$ & 123 & $137 / 63$ & 1.2 \\
\hline Load 5 & $9: 33$ & $7.1 / 125$ & 133 & $157 / 63$ & 1.1 \\
\hline ST max & $10: 31$ & $8.3 / 150$ & 146 & - & 1.1 \\
\hline Load 6 & $11: 24$ & $8.3 / 150$ & 147 & $157 / 66$ & 1.5 \\
\hline Load 7 & $13: 15$ & $9.5 / 175$ & 160 & $163 / 64$ & 1.7 \\
\hline Load 8 & $15: 04$ & $10.7 / 225$ & 169 & $161 / 73$ & 2.3 \\
\hline Load 9 & $17: 12$ & $11.9 / 225$ & 180 & $180 / 69$ & 2.5 \\
\hline Load 10 & $18: 36$ & $13.1 / 250$ & 182 & $194 / 83$ & 3.2 \\
\hline Rest & $1: 00$ & $1.2 / 0$ & 155 & & 4.1 \\
\hline Rest & $2: 00$ & $1.2 / 0$ & 128 & $139 / 89$ & 2.8 \\
\hline Rest & $3: 00$ & $1.2 / 0$ & 122 & $144 / 60$ & 1.8 \\
\hline Rest & $4: 00$ & $1.2 / 0$ & 120 & - & 1.3 \\
\hline EOT & $4: 55$ & $1.2 / 0$ & 114 & $144 / 69$ & 1.2 \\
\hline & & & Source: Babić $(2020)$ & & \\
\hline
\end{tabular}

Graph 1. Comparison of workload Mets and blood pressure $\mathrm{mmHg}$

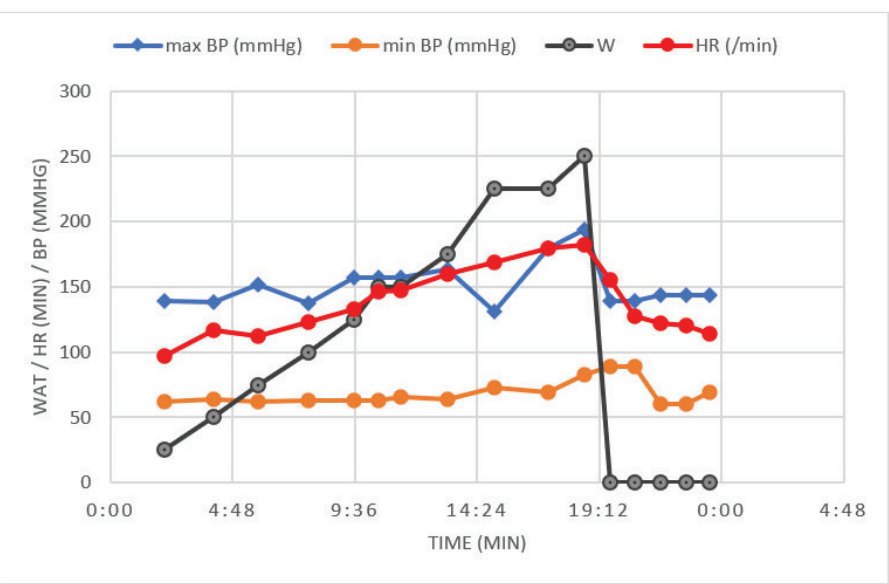

Source: Babić (2020) 
ECG before loading: SR freq. 90 / min, medium el. os, Neat. RR before loading 139/62 mmHg. ECG during load: SR. Max. Freq. 184 / min. No major changes in T wave and ST coupling, no rhythm disturbance. ECG after loading at 5 minutes recovery: SR freq. $115 \mathrm{rpm}$ medium e. RR at 5 minutes recovery $144 / 69 \mathrm{mmHg}$. A load of $250 \mathrm{~W}-13.1 \mathrm{MET}$ ( $117 \%$ of theoretical maximum load) with a maximum pulse of 184 / min ( $94 \%$ of theoretical maximum pulse) was achieved. At maximum load, RR 194/83 mmHg is registered. During load as well as after load, without significant changes in T wave and ST coupling, without rhythm disturbance. Test terminated due to high load achieved.

Conclusion: functional capacity $117 \%$, very high KR ability. The coronary reserve test is electrocardiographically and clinically negative at a load of W250 (13.1 MET) at $94 \%$ of maximum pulse. Proper pressure movement, no arrhythmia.

\section{2 Polygon test}

The soldier demonstrated his readiness for the task he was tested through 3 load levels. At 1st level, the soldier was without additional equipment, and the course on which the test was conducted was crossed without significant difficulty. During the next 2, the load level was more difficult because it was loaded with $10 \mathrm{~kg}$ of equipment, it took longer to reach the specified path. Increased energy consumption and heart rate were also present. The last $3 \mathrm{rd}$, the level was the most difficult because the body of the soldier was loaded with $20 \mathrm{~kg}$ of equipment. He had to cross a $10 \mathrm{~km}$ long section, which required excellent physical fitness, good health ultimately for the whole body. The soldier has traveled the given path, but only for the reason that he was prepared for such a level of physical exertion, which is the soldier's daily routine. Soldier's workload expressed in (W) or MET. The workload was carried out in accordance with the Occupational Safety and Health Act (Official Gazette 71/74, 118/14 and 154/14), the Ordinance on Special Conditions of Work (Official Gazette 5/84) and the Law on Service in the Armed Forces of the Republic of Croatia. Results of level 1, 2 and 3 runs are shown in tables 4 and 5 while cardio BPM rate is shown in graph 2.

Table 4. Results while performing the test on a polygon for level of run 1, 2 and 3.

\begin{tabular}{|c|c|c|c|}
\hline Level & 1 & 2 & 3 \\
\hline Load of equipment & $0 \mathrm{~kg}$ & $10 \mathrm{~kg}$ & $20 \mathrm{~kg}$ \\
\hline Consumed & $941 \mathrm{kcal} / 3,952 \mathrm{~kJ}$ & $1177 \mathrm{kcal} / 4943 \mathrm{~kJ}$ & $1404 \mathrm{kcal} / 6739 \mathrm{~kJ}$ \\
\hline Beats & $177 \mathrm{bpm}$ & $178 \mathrm{bpm}$ & $184 \mathrm{bpm}$ \\
\hline Time & $01: 08 \mathrm{~h}$ & $01: 22$ & $01: 26 \mathrm{~h}$ \\
\hline Cardio load on training & 114 & 151 & 180 \\
\hline Subjective training load & 274 & 413 & 605 \\
\hline Subject estimation & $4 / 10$ & $5 / 10$ & $7 / 10$ \\
\hline Running index & 43 & 37 & 37 \\
\hline
\end{tabular}


T. Babić, M. Kršulja, M. Šupuković: Mechanical load caused by physical activity by wearing military... Zbornik Veleučilišta u Rijeci, Vol. 9 (2021), No. 1, pp. 387-399

Table 5. Results of BPM rate for top to bottom work load $0 \mathrm{~kg}, 10 \mathrm{~kg}$ and $20 \mathrm{~kg}$

\begin{tabular}{|c|c|c|c|}
\hline Level & 1 & 2 & 3 \\
\hline $\begin{array}{c}\text { Load of } \\
\text { equipment }\end{array}$ & $0 \mathrm{~kg}$ & $10 \mathrm{~kg}$ & $20 \mathrm{~kg}$ \\
\hline Duration & $01: 08: 35 \mathrm{~h}$ & $01: 22: 37 \mathrm{~h}$ & $01: 26: 25 \mathrm{~h}$ \\
\hline Distance & $9,62 \mathrm{~km}$ & $9,67 \mathrm{~km}$ & $9,62 \mathrm{~km}$ \\
\hline HR avg & $151 \mathrm{bpm}$ & $155 \mathrm{bpm}$ & $159 \mathrm{bpm}$ \\
\hline Calories & $941 \mathrm{kcal}$ & $1177 \mathrm{kcal}$ & $1404 \mathrm{kcal}$ \\
\hline HR min & $78 \mathrm{bpm}$ & $81 \mathrm{bpm}$ & $92 \mathrm{bpm}$ \\
\hline HR max & $177 \mathrm{bpm}$ & $178 \mathrm{bpm}$ & $184 \mathrm{bpm}$ \\
\hline Fat burn \% of Cal & $26 \%$ & $26 \%$ & $24 \%$ \\
\hline Pace avg & $07: 08 \mathrm{~min} / \mathrm{km}$ & $08: 33 \mathrm{~min} / \mathrm{km}$ & $08: 59 \mathrm{~min} / \mathrm{km}$ \\
\hline Pace max & $03: 17 \mathrm{~min} / \mathrm{km}$ & $04: 39 \mathrm{~min} / \mathrm{km}$ & $03: 47 \mathrm{~min} / \mathrm{km}$ \\
\hline Ascent & $295 \mathrm{~m}$ & $295 \mathrm{~m}$ & $290 \mathrm{~m}$ \\
\hline Descent & $300 \mathrm{~m}$ & $290 \mathrm{~m}$ & $290 \mathrm{~m}$ \\
\hline Cadence avg & $79 \mathrm{steps} / \mathrm{min}$ & $77 \mathrm{steps} / \mathrm{min}$ & $76 \mathrm{steps} / \mathrm{min}$ \\
\hline Cadence max & $104 \mathrm{steps} / \mathrm{min}$ & $88 \mathrm{steps} / \mathrm{min}$ & $100 \mathrm{steps} / \mathrm{min}$ \\
\hline & Source: Babić $(2020)$ &
\end{tabular}

Graph 2. Results of BPM rate for top to bottom work load $0 \mathrm{~kg}, 10 \mathrm{~kg}$ and $20 \mathrm{~kg}$

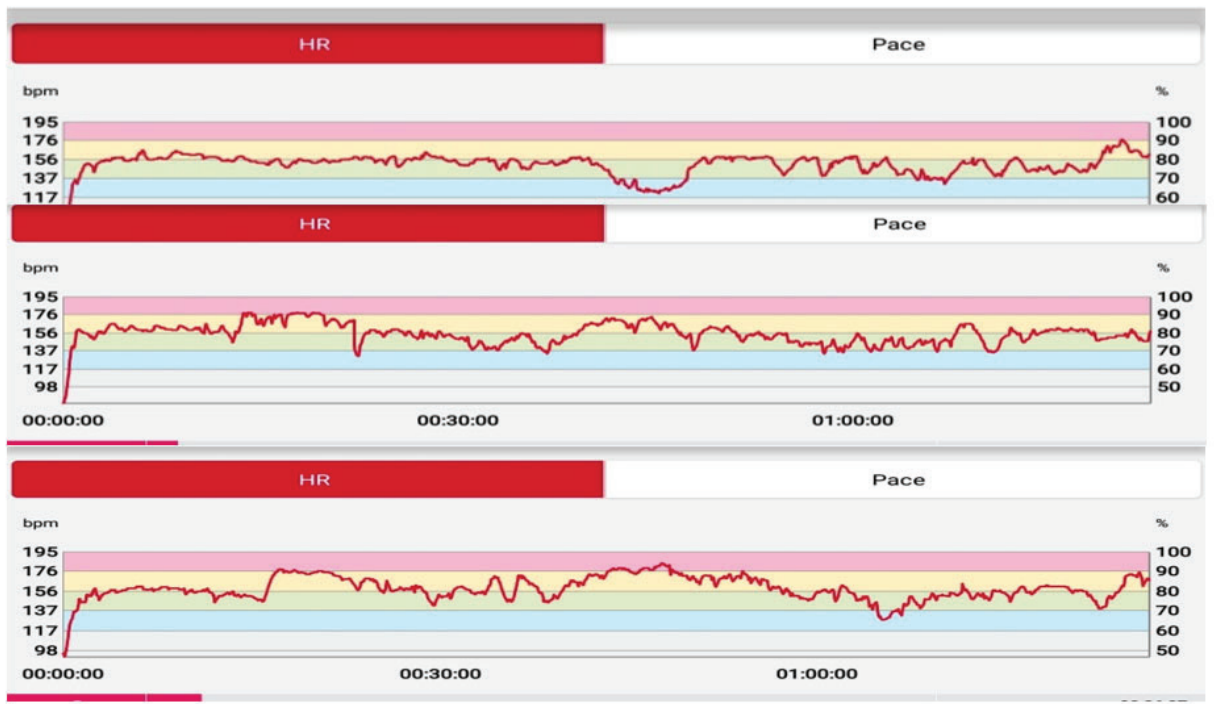

Source: Babić (2020) 
Results for different levels:

- Level 1, consumed $941 \mathrm{kcal}$ or 3,952 kJ and $177 \mathrm{bpm}$ beats in 01:08 h. Cardio Load based on training impulse was calculated as 114 , perceived subjective training load as 274 , and subject estimation 4/10. Running index was 43.

- Level 2, with $10 \mathrm{~kg}$ of combat equipment $178 \mathrm{bpm}$ and a power consumption of $1177 \mathrm{kcal}$ or $4943 \mathrm{~kJ}$ in a time of 01:22 h. Cardio Load based on training impulse was calculated as 151 , perceived subjective training load as 413 , and subject estimation 5/10. Running index was 37.

- Level 3, with $20 \mathrm{~kg}$ of combat equipment $184 \mathrm{bpm}$ and a power consumption of $1404 \mathrm{kcal}$ or $6739 \mathrm{~kJ}$, and it took 01:26 h for this final phase. Cardio Load based on training impulse was calculated as 180 , perceived subjective training load as 605 , and subject estimation 7/10. Running index was 37.

It took the soldier without equipment for 10-kilometer course only just over an hour. The energy consumed for this work is $3952 \mathrm{~kJ}$. More significant is the maximum frequency achieved (177 bpm). The terrain was demanding even during sudden climbs or falls, but there was no rest. There was a change in heart rate. Depending on the configuration of the terrain, the number of steps the soldier made on the polygon was adjusted.

In the middle diagram we see that the highest number is $178(\mathrm{bpm})$, while the average heart rate is 81 (bpm). The ascent is 295 meters, the descent or "fall" is 290 meters, the altitude is 426 meters. Energy consumption is $4943 \mathrm{~kJ}$. The difference between load 1 and load 2 in terms of energy consumption is not a significant deviation. Because of this, there was a slightly slower movement on the 2nd level, due to the additional weight, that is, the combat equipment of the soldiers. The difference in heart rate is due to the extra combat equipment of $10 \mathrm{~kg}$.

In the diagram above, the soldier had $184 \mathrm{bpm}$, which is $94 \%$ of the maximum aerobic load for him. An energy consumption of $6739 \mathrm{~kJ}$ represents a significantly higher energy consumption when compared to the same set time with less energy consumed. The difference in heart rate is due to the extra combat equipment of $20 \mathrm{~kg}$, then there was also a big climb. There was no rest during the exercise.

\section{CONCLUSION}

The research was undertaken in order to determine energy expenditure when doing work load related activity. Measuring mechanisms used in detecting fatigue were ergonomic test and measuring hart rate, calorie consumption, cardio load base with Polar digital watch and Polar website application. Fatigue risk management for a soldier fitness conditioning was examined with the intention to improve outcome energy expenditure by forecasting risk management. The soldier had $184 \mathrm{bpm}$, which is $94 \%$ of the maximum aerobic load for him. An energy consumption of $6739 \mathrm{~kJ}$ represents a significantly higher energy consumption when compared to the same set time with less energy consumed. 
First step was ergonomic test that determinates endurance limit and test was done in medical clinic Medico special hospital in the city of Rijeka. During ergonomic test maximum load 10 was measured, 13.1 / 250 MET/ W 182 beats / min, blood pressure 194/83 mm / Hg. The test subject endured $117 \%$ of overload and is conclude that he is prepared for excessive exercises.

Second step included monitoring spent energy while running at a predetermined course for a distance of around $9.6 \mathrm{~km}$ without load first run, with $10 \mathrm{~kg}$ of load second run and $20 \mathrm{~kg}$ third run. Data collected showed as expected increase of energy consumption form 3,952 kJ for $0 \mathrm{~kg}, 4943$ $\mathrm{kJ}$ for $10 \mathrm{~kg}$ and $6739 \mathrm{~kJ}$ for $20 \mathrm{~kg}$. According the results more load results with increased fatigue and decreases efficiency in work therefore safety risk management can be forecast. In attempt to determine preformed work characteristic the tiredness of employee was determined as:

1. Run, no load, subjective cardio training load as 274 , and subject estimation $4 / 10$.

2. Run, $10 \mathrm{~kg}$, subjective cardio training load as 413 , and subject estimation $5 / 10$.

3. Run, $20 \mathrm{~kg}$, subjective cardio training load as 605 , and subject estimation $7 / 10$.

When performing work, a healthy body metabolism is essential, especially when it comes to such levels of workload. With the proper intake of protein, fat, carbohydrates, minerals and other nutrients, the soldier's body was able to achieve maximum load. The results of the load test survey show that work requiring heavy workload can be performed if a person is admitted for the stated physical exertion. This involves the interaction of the soldier's metabolism, fitness, and protective equipment that protects or helps him with such a load. For this reason, it is important to achieve it with a healthy lifestyle, proper nutrition and sports activity.

It can be concluded that soldier fitness requires safety management policy by knowing risks of fitness preparation, energy expenditure with and without load, proper food supplement for increase of energy consumption. Therefore, fatigue monitoring and alertness for duty depend on reporting of fatigue during work, incident investigation for unusual circumstances and proper education about training is needed for energy losses detection of a soldier.

\section{REFERENCES}

Babić,T. (2020) Mehaničko opterećenje nošenja borbene opreme, Završni rad, Veleučilište u Rijeci.

Bender D. A. (2007) Introduction to Nutrition and Metabolism, Fourth Edition: ISBN-13: 978-1420043129, CRC Press;

Bognolo, D. et all. (2015) Procjena stanja temperature na mjestu rada u pekari, ITE-SAFETY 2015, ISBN 978-953-567898-4. Quimedia, Poreč. pp. 1-6.

Law on Service in the Armed Forces of the Republic of Croatia (Official Gazette 73/15, 75/15, 50/16 and 30/18) https:// www.zakon.hr/z/327/Zakon-o-slu\%C5\%BEbi-u-Oru\%C5\%BEanim-snagama-Republike-Hrvatske (01.08.2020)

Manore M, Meyer L. N.,Thompson J. (2009) Sport Nutrition for Health and Performance, second edition, ISBN-13: 9780-7360-8851-9, Thomson-Shore, Inc.

Occupational Safety and Health Act (Official Gazette 71/14, 118/14 and 154/14) https://www.zakon.hr/z/167/Zakono-za\%C5\%A1titi-na-radu, (01.06.2020).

Ordinance on Occupational Safety at Manual Handling of Loads (OG No. 42/05), https://narodne-novine.nn.hr/clanci/ sluzbeni/2005_04_42_818.html, (01.06.2020). 
T. Babić, M. Kršulja, M. Šupuković: Mechanical load caused by physical activity by wearing military... Zbornik Veleučilišta u Rijeci, Vol. 9 (2021), No. 1, pp. 387-399

Ordinance on Occupational Safety at Work (Official Gazette 29/13), Article 24., https://narodne-novine.nn.hr/clanci/ sluzbeni/2013_03_29_509.html, (01.06.2020).

Ordinance on Special Conditions of Work (Official Gazette 5/84). https://www.pmf.unizg.hr/_download/repository/ Pravilnik_o_poslovima_s_posebnim_uvjetima_rada.pdf (01.06.2020).

Pupavac, D., Bognolo, D., Kršulja, M. (2018) Statistical analysis and grade of occupational injuries in the Republic of Croatia, Sigurnost 60 (2018.), 3; pp. 225-233 doi:10.31306/s.60.3.5

Regent, A., Kršulja, M. (2015) Fizikalne štetnosti - Zbirka riješenih zadataka, Rijeka: Veleučilište u Rijeci, 2015, ISBN: 978 953-6911-82-0 
Izvorni znanstveni rad

https://doi.org/10.31784/zvr.9.1.24

Datum primitka rada: 3. 7. 2020.

\section{MEHANIČKO OPTEREĆENJE UZROKOVANO TJELESNOM AKTIVNOŠĆU NOŠENJA VOJNE OPREME}

\section{Tomislav Babić}

Student, Veleučilište u Rijeci, Vukovarska 58, 51000 Rijeka, Hrvatska; e-mail: tomislavbabic94@gmail.com.

\section{Marko Kršulja}

Dr. sc., docent, Sveučilište u Puli, Zagrebačka 30, 52100 Pula, Hrvatska; e-mail:mkrsulja@unipu.hr

\section{Maja Šupuković}

Asistentica, Veleučilište u Rijeci, Vukovarska 58, 51000 Rijeka, Hrvatska; e-mail:msupukov@veleri.hr

\section{SAŽETAK}

U ovom radu istražuje se umor profesionalnog vojnika uzrokovan aktivnom fizičkom aktivnošću i ograničenjima izdržljivosti. Rezultat radnog opterećenja jedan je od pokazatelja kako obuka, pripremljenost i druge stečene radne vještine mogu pridonijeti ljudskom tijelu kao velikom radnom „stroju.. Provedeno je ergometrijsko ispitivanje i terenski test za kondicijsko stanje vojnika i potrošnja energije mjereno je s obzirom na razinu metabolizma u tijelu. Terensko ispitivanje sastojalo se od staza na poligonu od $10 \mathrm{~km}$ i različitih opterećenja, a praćena je i potrošnja energije. Radno opterećenje uspoređeno je sa zakonima o zaštiti na radu. Rezultati su pokazali razliku u uvjetima radnog opterećenja i brzini vrtnje, što je omogućilo određivanje mjesta odmora i sigurnosti u uvjetima treninga.

Ključne riječi: umor, metabolizam, potrošnja energije, zaštita na radu, vojnik 
